\title{
Designing Android-Based Software for Anthropometry, Hearing Test, and Visual Test to Monitor Children Developmental Status
}

\author{
${ }^{1}$ Zalni Rahmad Anakampun, ${ }^{1}$ Nabilah, ${ }^{1}$ Cut Hasina Sonia, ${ }^{2}$ Masdar Maulana, ${ }^{3}$ Firman Parlindungan, ${ }^{4}$ Muhammad Reza \\ Firdaus
}

\begin{abstract}
${ }^{1}$ Department of Public Health, Faculty of Public Health, University of Teuku Umar, West Aceh, Indonesia ${ }^{2}$ Department of Information Technology, Faculty of Engineering, University of Teuku Umar, West Aceh, Indonesia ${ }^{3}$ Department of Communication Science, Faculty of Social and Political Sciences, University of Teuku Umar, West Aceh, Indonesia

${ }^{4}$ Community Health Center of Suak Ribee, West Aceh, Indonesia

Corresponding author: Firman Parlindungan, e-mail: firman@utu.ac.id

Co-author: ZRA: radmadzalni05@gmail.com, N: nabilah.putri901@gmail.com, CHS: cuthanisasonia01@gmail.com, MM: masdarmaulana01@gmail.com.
\end{abstract}

Submitted:31/08/2021 Revised: 18/10/2021 Accepted: 22/10/2021 Published online: 31/10/2021

DOI: https://doi.org/10.35308/j-kesmas.v7i2.4070 How to cite this article: Anakampun, Z.A., Nabilah., Sonia, C.H., Maulana, M., Parlindungan, F., Firdaus, M.R. (2021). Designing android-based software for anthropometry, hearing test and visual test to monitor children developmental status. J-Kesmas: Jurnal Fakultas Kesehatan Masyarakat (The Indonesian Journal of Public Health). 8(2): 49-54.

\begin{abstract}
The World Health Organization (WHO) in 2018 reported that the prevalence for children under five with growth and development disorders was $28.7 \%$, and Indonesia was included in the third country with the highest prevalence in the Southeast Asia region. As such, monitoring child growth and development is pivotal to determine necessary intervention and prevention. With technological advancement, monitoring child growth and development has become more accessible. The main objective of this paper is to explain the process of designing an Android software application for anthropometry, hearing test, and visual test to monitor children's developmental status. We employed to research and development methods, including need analysis, data collection, application design, user trial, and evaluation. The findings showed that the application could monitor growth and development in children from the age of zero to 72 months based on anthropometric testing related to auditory and visual stimulation in children. The application is useful in detecting the growth and development of children based on the results of the child's stimulation response. Based on the results of user trials by medical experts, parents, technological experts, it can be concluded that the software is applicable in monitoring the status of children's growth and development.
\end{abstract}

Keywords: stunting, anthropometry, children development, visual test, hearing test, android application

\section{Introduction}

Stunting is a condition of toddlers with a length or height that is less than their age. This condition is measured by a length or height that is more than minus two standard deviations of the median child growth standard of the WHO (World Health Organization). Toddlers with stunting conditions will have difficulty in achieving optimal physical and cognitive development in the future. The incidence of stunting under five is a major nutritional problem faced by Indonesia. It includes chronic nutrition problems due to many factors such as economic conditions, nutrition of pregnant women, infant morbidity, and lack of infant nutrition (Kemenkes RI, 2018).

Indonesia is one of the countries with the highest burden of stunting and wasting in children globally. According to WHO data, Indonesia is ranked third with the highest prevalence of stunting in the South_East Asian Region after Timor Lester (50.5\%) and India $(38.4 \%)$ at $36.4 \%$. The prevalence of very short and short toddlers aged 0-59 months in Indonesia based on the 2018 Riskesdas was $11.5 \%$ and $19.3 \%$, respectively. According to data from the Ministry of Health in 2019, 1 in 4 children under five in Indonesia suffers from stunting, with a prevalence of $27.7 \%$ (Kemenkes RI, 2020).

The number of nutritional problems in children due to COVID-19 in Indonesia could increase sharply due to overburdened health facilities, disrupted food supply chains, and loss of income due to the pandemic. UNICEF estimates show that in the absence of timely action, the number of children experiencing acute wasting or malnutrition under five years of age could increase globally by around $15 \%$. Children who experience wasting are more likely to experience stunting (UNICEF Indonesia, 2020). 
Three provinces with the prevalence of concise and short nutritional status in under-fives based on Riskesdas 2018 are Aceh, West Sulawesi, and Nusa Tenggara (Kemenkes RI, 2018). The data shows that the province of Aceh for stunting in children under two years (Baduta) is ranked 1st out of 34 provinces with a prevalence of $37.9 \%$. Meanwhile, Aceh Province is ranked 3 rd out of 34 provinces in Indonesia, with a prevalence of stunting in children under five, $37.1 \%$. So, based on the WHO criteria, the prevalence of stunting in Aceh province is included in the very high and high category, namely areas with stunting prevalence between 30-39.9\% (Aceh Provincial Health Office, 2018).

Data from the West Aceh District Health Office from 2020 to June shows that the Cot Seumeureung Health Center, Samatiga District is the work area with the highest number of stunting in 13 health centers in West Aceh with a total of 79 cases, followed by Layung Health Center with 45 instances and West Woyla Health Center as many as 41 cases (West Aceh District Health Office, 2020).

There are three efforts in preventing stunting, namely from parenting, diet, and clean water and sanitation. Of the three efforts, parenting efforts received particular attention in stunting prevention efforts. One of the forms of parenting provided is knowledge about health and nutrition and good health services such as Posyandu and immunization. Monitoring the height and weight of toddlers at the Posyandu and special clinics for children can make it easier for parents to know the initial symptoms of the disorder and its handling (Director of Community Nutrition, 2019)

The height and weight of toddlers need to be monitored regularly so that if a toddler experience stunting, it will be quickly detected and treated. The government, through the Posyandu program, measures height and weight regularly every month. Cadres as Posyandu drivers are the key to the success of Posyandu (Susilowati, 2012). The duties of cadres in posyandu are five tables, namely registration, measurement of size and weight, recording, nutrition counseling, and health services. However, in practice, there are still Posyandu activities that are stopped until the measurement and recording activities are only due to a lack of knowledge of cadres about determining the nutritional status of children under five. Cadres only take weight and height measurements and then record them in the visit book and interpret them as limited to increasing, constant, or decreasing from the previous calculation without interpreting the measurement results by looking at the child's nutritional status (Adistie, Lumbantobing, \& Maryam, 2018).

The absence of information from Posyandu (Integrated Health Service Post) cadres about the nutritional status of children under five causes many mothers who do not know the nutritional status of their children because so far the measurement of nutritional status has been carried out at the Puskesmas (Community Health Center) level after reporting by the Village Midwife with the distance between reporting time and measuring nutritional status is very long due to the burden work of officers at the Puskesmas, so that the nutritional status of children is known too late which in the end is too late to tackle stunting cases.

In addition, information related to nutritional status is only conveyed to mothers who have toddlers with problems because, at the same time, an intervention is carried out so that other mothers who do not receive intervention are only limited to knowing that their child has no problems but does not accurately know the nutritional status of their children.

This research is supported by a previous study conducted by Rahmandiani et al. (2019) regarding the relationship of mother toddler knowledge about Stunting with maternal characteristics and Information Sources in Hegarmanah Village, Jatinangor District, Sumedang Regency. A similar study conducted by Suryagustina et al. (2018) stated that the lack of information significantly affects the level of a mother's knowledge about the nutritional status of children.

So we need a tool to measure nutritional status quickly and can be recorded like the WHO Anthro and WHO AnthroPlus applications so that Posyandu cadres can provide information on nutritional status directly to mothers of children under five after measurement also become material for monitoring the nutritional status of these toddlers. WHO Anthro application is a software developed to facilitate the application of motor growth and development of individuals, while populations of children up to the age of 5 years and children aged 5-19 years use WHO AnthroPlus (Nursanyoto \& Tanu, 2017).

\section{Methods}

This research employed Research and Development design. The steps taken include designing, implementing, and testing the applications. Figure 1 below shows the steps of the study: 


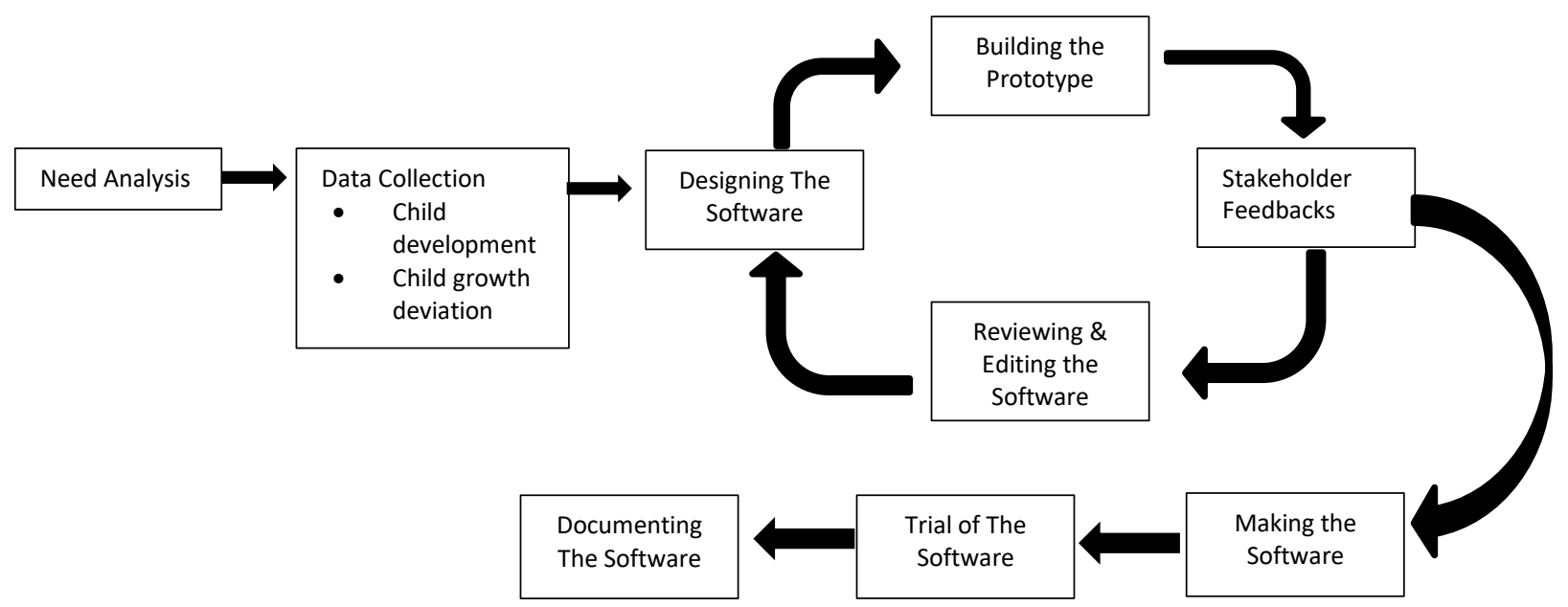

Figure 1. Research Method Procedure

Need analysis is conducted as follows: Observation- The researchers conducted field research at the Cot Seumeureung Health Center to find out how far the monitoring of children's growth and development during the toddler years. The Puskesmas shows early detection using the Early Detection of Child Growth and Development instrument and manually calculates the number of children's abilities. To find out that a child has a growth and development disorder, the Puskesmas performs an estimation process, or it can be said that there is still no special calculation method so that early detection of child growth and development can only be seen clearly if the child has a delay disorder that differs significantly between average child growth and development. And abilities that children should have.

Interview - The researchers conducted direct questions and answers to the health medical team at the Puskesmas as many as five people as data in the field, as well as conducting questions and answers to employees and child development experts working at the Cot Seumeureung Health Center as many as two people to get theories about early detection growth and development of children and deviations in child growth. Growth in ideal body weight (BB) for children has three groups, namely the age of zero to one year: three times the birth weight; one to two years of age: four times the birth weight and over two years of age have normal growth of an average of two kg/year. For body length (PB) the average birth is $50 \mathrm{~cm}$. Age zero to one year is increased by $50 \%$;
One to four years increase by $50 \%$; four to six years twice PB was born. For Head Circumference (LK) the average birth is $35-37 \mathrm{~cm}$. Zero to one year of age increases by three to four $\mathrm{cm}$; the age of one to six years increases by two to three $\mathrm{cm}$; six years old 54$55 \mathrm{~cm}$. How to measure head circumference is to loop the measuring device from the frontal to the ear bone then to the occipitalis back to the frontalis with a soft measuring instrument.

Library Research - The researchers collected data or sources obtained from various references regarding child development and making user friendly interface designs that can assist the research team in completing application development.

Furthermore, data collection is done by first developing the instrument. The making of instruments in this study was used to determine the stages of child growth and development, and also their deviations. If it is said that there is a deviation in child growth and development, early stimulation is needed to provide first aid for child growth and development. The instrument was made by the research team, and validated by child development experts working at the Cot Seumeureung Health Center, Aceh Barat. Then the research instrument was filled in by the medical team working at the Public Health Center, in order to determine the implementation of the detection of child growth and development carried out by the health medical team at the Health Center. Child development instruments used pre-screening developmental questionnaires, hearing tests and visual tests in monitoring children's growth and development status. 


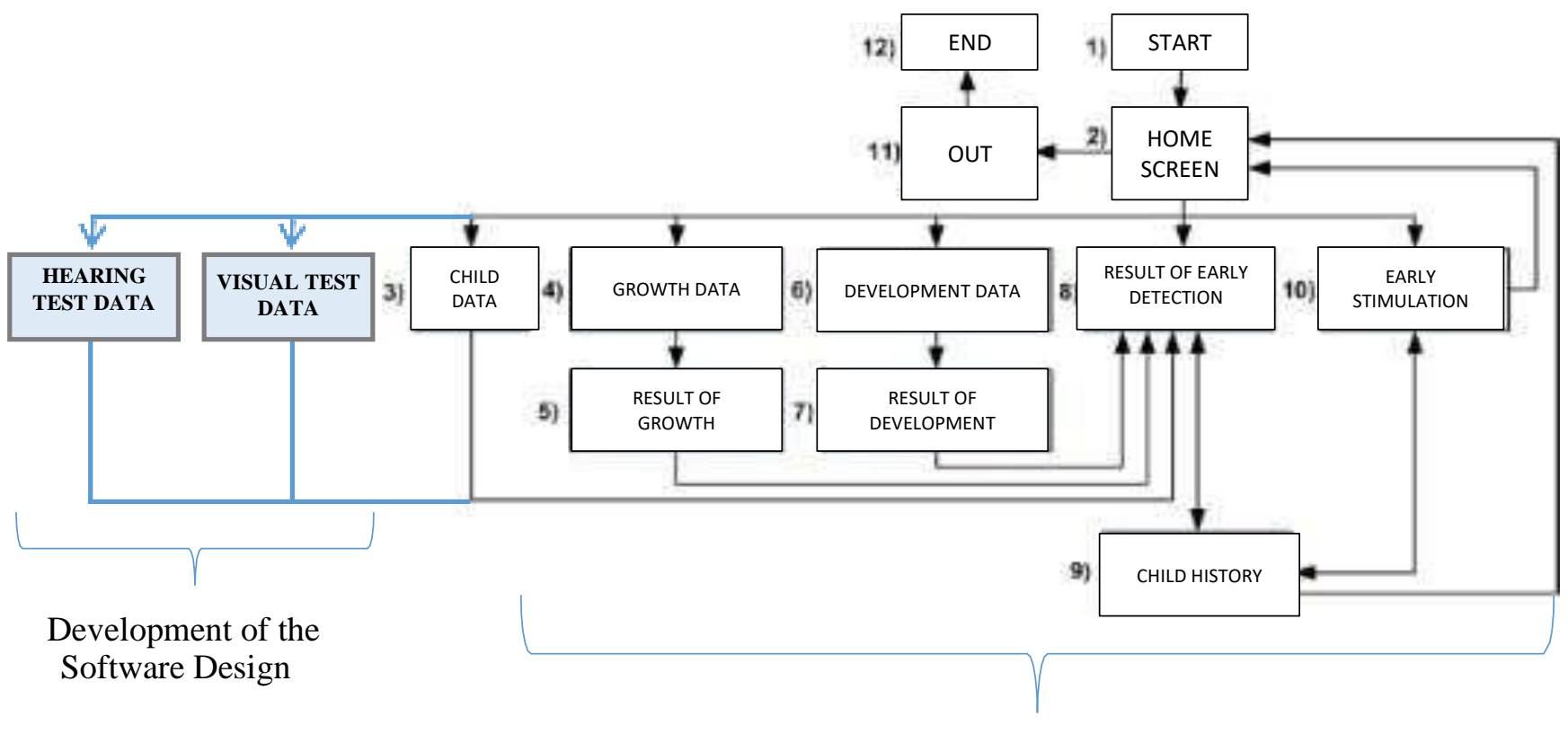

Software Design By Saurina

(2016)

Figure 2. Design Interface of the Software Development

The next step is designing the software. Figure 2 shows the main menu in the application, namely: (1) Child Data. Users can enter data about children including: name, date, month and year of birth, gender. (2) Growth Data. Users can enter data regarding the child's growth including: height, weight and head circumference. (3) Development Data. Users can enter data regarding child development. Child development instruments are adapted to children's data. (4) Early Detection Results. Users can see the results of early detection of children, the results of growth and results of child development, which are stored in the child's history. (5) Early Stimulation. Users can view information about early stimulation that can be given to children and of course it is stored in the child's history. In the application that we will make there are additional 2 menus, namely: (6) Visual test Data and (7) Hearing test Data, so this is what distinguishes our application from the application built by Saurina (2016).

The last step is user testing. The application was tested on users, namely two child development experts from the Cot Seumeureung Health Center, five nurses who served as a health medical team from the Puskesmas and 25 parents who had different child development problems.

\section{Results}

In testing this application using two Android- based smartphone units Table 1 contains information about the specifications on the device used.

Table 1. Spesifikasi Smartphone Android

\begin{tabular}{ll}
\hline Samsung galaxy a51 & Samsung galaxy s8plus \\
\hline Display 1080 x 2400 pixel & Display 1440 x 2960 pixel \\
Android Os 10 (queen cake) & Os 9 (pie) \\
Prosesor Exynos 9611 & Exynos 8895 \\
CPU octa-core & Octa-core 2.3 GHz
\end{tabular}

(Primary data, 2021)

Table 2. Results of the Child Development Expert Trial Questionnaire

\begin{tabular}{lcl}
\hline Indicator & $\%$ & Remark \\
\hline Conformity of content \& purpose & 84 & Strongly \\
Conformity of child stimulation & 80 & Agree \\
$\begin{array}{l}\text { Conformity of child growth and } \\
\text { development }\end{array}$ & 80 & Agree \\
\hline \multicolumn{1}{c}{ Overall Result } & Agree \\
\hline
\end{tabular}

(Primary data, 2021)

Table 3. Results of the Health Medical Team Trial Questionnaire

\begin{tabular}{lll}
\hline Indicator & $\%$ & Remark \\
\hline Conformity of content \& purpose & 89 & Strongly \\
Conformity of the features & 79 & Agree \\
Conformity of the result & 80 & Agree \\
& & Agree \\
\hline Overall Result & 82 & Very Good \\
\hline (Primary data, 2021) & &
\end{tabular}


Table 4. Results of Parents Trial Questionnaire

\begin{tabular}{lcl}
\hline Indicator & $\%$ & Remark \\
\hline Application view & 85 & Strongly \\
Ease of operation & 79 & Agree \\
Relevance & 82 & Agree \\
Accuracy & 78 & Agree \\
Language use & 81 & Agree \\
& & Strongly \\
& & Agree \\
\hline \multicolumn{1}{c}{ Overall Result } & 81 & Very Good \\
\hline
\end{tabular}

(Primary data, 2021)

\section{Discussion}

In the child data menu, the user enters the child's name, age, origin, and date, month, year of birth. Then the user can use the anthropometric features consisting of: sight, hearing and measuring the child's height, then the application will display the results of the stimulation and the child's height. Based on the data from the stimulation results and the child's height, it can be known, if the child experiences growth and development problems from the stimulation, the results of the response or no response will come out.

The results of auditory and visual stimulation in children depend on the child's response to the five images then the results of the visual power test are in accordance with the child's development at his age. In the hearing test, if the child responds to a sound instrument that is sounded at a distance of $30 \mathrm{~cm}$, the child's stimulation development is normal and in accordance with the child's development at his age. Figure 3 is the result of measuring the child's height taken using a camera on a smartphone and on a banner that has an Aruco Marker so that the level of accuracy becomes more accurate.

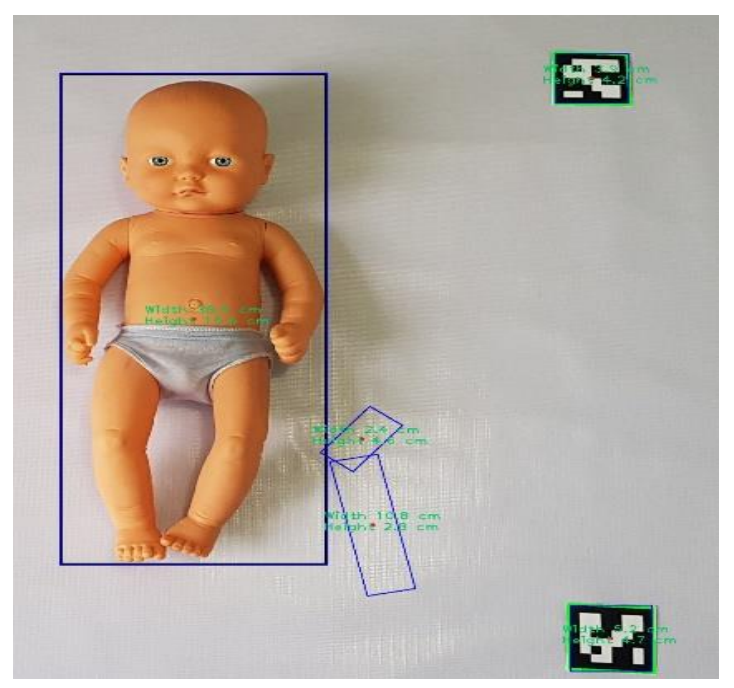

Figure 3. Height Measurement Outlook
The application was tested on users, namely two child development experts from the Cot Seumeureung Health Center, five nurses who served as a health medical team from the Puskesmas and 25 parents who had different child development problems. Table 2 is a questionnaire answered by child growth and development experts, there are 10 questions that include 3 main indicators consisting of: first, the suitability of content and goals, secondly the suitability of children's stimulation, thirdly the suitability of children's growth and development. In making an assessment using a scale of one to five with a range, strongly disagree to strongly agree. By interpreting the score using a Likert scale (Hikmah, 2017).

\section{Conclusion}

Based on the results of research, it can be concluded that: 1) the application can be used to determine stimulation in children from the age of zero to 72 months based on anthropometric testing related to auditory and visual stimulation in children. 2) the application is useful in detecting the growth and development of children based on the results of the child's stimulation response. 3) Based on the results of application trials by experts on child growth and development, it was (83\%), for the health medical team (82\%), and for parents $(80 \%)$. Based on the results of trials conducted by the three groups, it can be concluded that this application can be used by parents in monitoring the status of children's growth and development.

\section{Acknowledgement}

This research was made possible by the Program Kreativitas Mahasiswa (Student Creativity Program) 2021 of the Directorate General of Higher Education, Ministry of Education, Culture, Research, and Technology.

\section{Author Contribution and Competing Interest}

All of the research processes were conducted by the first, second, third, and fourth researchers under the supervision of the fifth and sixth researchers. The fifth researcher was the principal investigator. There is no competing interest in this research.

\section{References}

Chesney, R, W. (2013). The disappearance of diseases, conditions, and disorders of 
childhood. The Journal of Pediatrics. 162 (5):903-905.

Depkes RI. (2014). Pedoman umum gizi seimbang tahun 2014. Departemen Kesehatan Republik Indonesia. Jakarta.

Dinas Kesehatan Provinsi Aceh. (2018). Profil kesehatan provinsi aceh. Dinas Kesehatan Provinsi Aceh. Banda Aceh.

Dinas Kesehatan Kabupaten Aceh Barat. (2018). Profil kesehatan kabupaten aceh barat. Dinas Kesehatan Kabupaten Aceh Barat. Aceh Barat.

Grantham-McGregor, S., Cheung, Y. B., Cueto, S., Glewwe, P., Richter, L., Strupp, B., dan International Child Development Steering Group. (2007). Developmental potential in the first 5 years for children in developing countries. The Lancet, 369 (9555): 60-70.

Kemenkes RI. (2014). Peraturan menteri kesehatan republik indonesia nomor 66 tahun 2014 tentang pemantauan pertumbuhan, perkembangan dan gangguan tumbuh kembang anak. Kemenkes Republik Indinesia. Jakarta.

Latino, R., Gomes, G.L.L., dan Nobrega. L.M.M. (2015). Anxiety in children following hospitalization: a proposal for a nursing diagnosis. Original Article. 23 (5):963-970.
IDAI. 2013. Mengenal keterlambatan perkembangan umum pada anak. Ikatan Dokter Anak Indonesia. Jakarta.

Saurina, N. (2016). Aplikasi Deteksi Dini Tumbuh Kembang Anak Usia Nol Hingga Enam Tahun Berbasis Android. Jurnal Buana Informatika, 7(1):65-74.

Soetjiningsih., Ranuh, G. (2013). Tumbuh kembang anak. Edisi 2. EGC. Jakarta.

Suryanto, S., Purwandari, H., dan Mulyono, W.A. 2014. Dukungan keluarga dan sosial dalam pertumbuhan dan perkembangan personal sosial, bahasa dan motorik pada balita di kabupaten banyumas. Jurnal Kesehatan Masyarakat, 1(1):103-109.

Uce, L. 2017. The golden age: masa efektif merancang kualitas anak uin ar-raniry. Skripsi. Universitas Islam Negeri Ar-Raniry, Aceh.

WHO. 2016. Nutrition challenges. URL: http://www.who.int/nutrition/challenges/en/Dia kses tanggal 22 Januari 2021.

WHO. 2018. Levels and trends in child malnutrition. URL : http://www.who.int/nutgrowthdb. Diakses Tanggal 22 Januari 2021.

Widodo, Danang Wahyu dan Boedijanto, Eko. 2014. Perancangan sistem pakar deteksi dini tumbuh kembang anak berbasis multimedia. Jurnal Ilmiah Sisfotenika, 4 (2):128-139. 